\title{
IMPLEMENTASI KEBIJAKAN BELAJAR DARI RUMAH DENGAN TATANAN NORMAL BARU PADA SEKOLAH DASAR DI KECAMATAN BULAK KOTA SURABAYA
}

\author{
${ }^{1}$ Nathasia May Afistha, ${ }^{2}$ Ananta Prathama \\ 1,2Administrasi Publik Fakultas IImu Sosial dan IImu Politik Universitas Pembangunan Nasional \\ "Veteran" Jawa Timur Surabaya \\ nathasiamayafistha@gmail.com, prathama.ananta@gmail.com \\ Kota Surabaya Jawa Timur Indonesia
}

\begin{abstract}
The spread of COVID-19 in Indonesia is increasing every day. urged the government to immediately deal with the COVID-19 pandemic by making various policies such as implementing a lockdown, social distancing, physical distancing, self-isolation and LargeScale Social Restrictions (PSBB). With this government policy, it certainly has a big impact in various aspects of life, especially in the aspect of education in Indonesia. With the implementation of PSBB, it encourages the government to issue policies on the implementation of education in Indonesia, because after all the learning process must continue so that the objectives of education can be achieved as a whole. The purpose of this study is to describe the implementation of learning from home policies with the new normal order in elementary schools in Bulak District, Surabaya City. The theory used in this research is the theory of implementation model by Edward III. This type of research uses descriptive qualitative. The results of this study indicate that: (1) Communication has been implemented well; (2) Resources are well implemented but staff are not sufficient; (3) The disposition has been implemented very well; (4) The bureaucratic structure is well implemented.
\end{abstract}

Keywords: covid-19, elementary school; learning from home; policy implementation

\begin{abstract}
Abstrak
Angka penyebaran COVID-19 di Indonesia semakin meningkat setiap harinya. mendesak pemerintah untuk segera menangani pandemi COVID-19 dengan membuat berbagai kebijakan seperti menerapkan lockdown, social distancing, phsycal distancing, isolasi mandiri dan Pembatasan Sosial Berskala Besar (PSBB). Dengan adanya kebijakan pemerintah tersebut tentu menimbulkan dampak yang besar dalam berbagai aspek kehidupan, khususnya pada aspek pendidikan di Indonesia. Dengan diterapkannya PSBB mendorong pemerintah untuk mengeluarkan kebijakan terhadap pelaksanaan pendidikan di Indonesia, karena bagaimanapun proses pembelajaran harus tetap berlangsung agar tujuan dari pendidikan dapat tercapai secara utuh. Tujuan penelitian ini untuk mendeskripsikan implementasi kebijakan belajar dari rumah dengan tatanan normal baru pada sekolah dasar di Kecamatan Bulak Kota Surabaya. Teori yang digunakan dalam penelitian ini adalah teori model implementasi oleh Edward III. Jenis penelitian ini menggunakan deskriptif kualitatif. Hasil penelitian ini menunjukkan bahwa: (1) Komunikasi telah dilaksanakan dengan baik; (2) Sumber daya diimplementasikan dengan baik namun staff belum tercukupi; (3) Disposisi telah dilaksanakan dengan sangat baik; (4) Struktur birokrasi terlaksana dengan baik.
\end{abstract}

Kata Kunci: belajar dari rumah; covid-19, implementasi kebijakan; sekolah dasar 


\section{PENDAHULUAN}

Pada akhir tahun 2019 dunia dikejutkan dengan mewabahnya pneumonia baru yang bermula dari Wuhan, Provinsi Hubei yang kemudian menyebar dengan cepat ke seluruh dunia, tidak terkecuali Negara Indonesia. Dengan terus meningkatnya kasus positif virus corona di Indonesia mendesak pemerintah untuk segera menangani pandemi COVID-19 dengan membuat berbagai kebijakan seperti menerapkan lockdown, social distancing, phsycal distancing, isolasi mandiri dan Pembatasan Sosial Berskala Besar (PSBB). Dengan adanya kebijakan pemerintah tersebut tentu menimbulkan dampak yang besar dalam berbagai aspek kehidupan, khususnya pada aspek pendidikan di Indonesia. Dengan diterapkannya PSBB mendorong pemerintah untuk mengeluarkan kebijakan terhadap pelaksanaan pendidikan di Indonesia, karena bagaimanapun proses pembelajaran harus tetap berlangsung agar tujuan dari pendidikan dapat tercapai secara utuh.

Pada aspek pendidikan, pemerintah berupaya meminimalisir dampak tersebut dengan mengeluarkan Surat Edaran Mendikbud Nomor 4 Tahun 2020 tentang Pelaksanaan Kebijakan Pendidikan dalam Masa Darurat Penyebaran Coronavirus Disease (COVID-19), yang kemudian ditindaklanjuti dengan Surat Edaran Sesjen Mendikbud Nomor 15 Tahun 2020 tentang Pedoman Penyelenggaraan Belajar dari Rumah dalam Masa Darurat Penyebaran COVID-19 sebagai salah satu upaya pemerintah untuk tetap mewujudkan terlaksananya pendidikan meskipun ditengah pandemi.

Pembelajaran merupakan hal utama dalam pendidikan yang pelaksanaannya dilakukan secara terus menerus. Menyadari pentingnya pendidikan pemerintah merumuskannya dalam Undang-Undang Nomor 2 Tahun 1989 tentang Tujuan Nasional Pendidikan. Pendidikan mempunyai arti usaha sadar untuk menyiapkan peserta didik melalui kegiatan bimbingan, pengajaran, dan latihan bagi peranannya di masa yang akan datang. Dalam menindaklanjuti anjuran Kementerian Pendidikan dan Kebudayaan (Kemendikbud) tentang rambu-rambu pelaksanaan kegiatan akademik dalam masa darurat maka ditetapkan program belajar dari rumah yang telah diterapkan dari berbagai tingkatan pendidikan di Indonesia (Maulah, A., \& Ummah, 2020:50).

Belajar dari Rumah (BDR) merupakan sebuah proses pembelajaran yang dilakukan oleh siswa dan guru di rumah masing-masing, berbagai cara dilakukan agar proses pembelajaran dapat berlangsung dan peserta didik tetap merasakan pendidikan meskipun tidak menutut ketuntasan kurikulum. BDR dilakukan dengan bantuan media atau perangkat elektronik berupa smartphone, komputer, maupun laptop yang terhubung dengan jaringan internet (Prasetyaningtyas, 2020). Dengan adanya kebijakan BDR ini, diharapkan dapat memutus rantai penularan penyakit COVID-19 pada aspek pendidikan. Namun dalam pelaksanaannya masih terdapat permasalahan. Retno Listiyarti selaku Komisioner KPAI 


\section{Journal Publicuho}

ISSN2621-1351 (online), ISSN 2685-0729 (print)

Volume 4 Number 2 (May-July), (2021)pp. 711-718

Accredited SINTA SK.NOMOR 28/E/KPT/2019

Open Access at:http://ojs.uho.ac.id/index.php/PUBLICUHO/index DOI: 10.35817/jpu.v4i2.19064

mengungkapkan pihaknya mengumpulkan aduan tersebut sejak 16 Maret hingga 9 April 2020 dan membaginya dalam beberapa poin yaitu 1) penugasan yang terlalu berat dengan waktu yang singkat; 2) banyak tugas merangkum dan menyalin dari buku; 3) jam belajar masih kaku; 4) keterbatasan kuota untuk mengikuti pembelajaran daring; 5) sebagian siswa tidak memiliki gawai pribadi sehingga kesulitan mengikuti pembelajaran (Arifa, 2020:15).

Selain itu, kejenuhan siswa dan guru yang menjadi bingung dalam memberikan pembelajaran selama pandemi COVID-19 juga menjadi poin terkait aduan pelaksanaan BDR. Banyak guru yang bingung karena telah memberikan banyak materi dan tugas sebelumnya sedangkan proses pembelajaran harus tetap berlangsung. Tidak hanya itu, kendala lain juga dirasakan oleh Orang tua/wali murid juga merasa kesulitan.

Kota Surabaya merupakan salah satu kota yang terpapar virus COVID-19 dengan jumlah tertinggi di Jawa Timur. Dampak yang ditimbulkan dari penyebaran virus ini sangat besar, terutama pada bidang pendidikan. pada 10 Juni 2020 Walikota Surabaya mengeluarkan Peraturan Walikota Surabaya Nomor 28 Tahun 2020 tentang Pedoman Tatanan Normal Baru pada Kondisi Pandemi Corona Virus Disease 2019 (COVID-19) di Kota Surabaya. Dalam peraturan tersebut terdapat 12 poin yang berlaku mengenai protokol kesehatan di semua sektor lapisan masyarakat, salah satunya diatur mengenai kebijakan pendidikan di lingkungan sekolah, yaitu berisi mengenai kegiatan belajar mengajar atau proses magang, dan praktek kerja lapangan tetap dianjurkan dilakukan dari rumah atau tempat tinggal masing-masing. Jika pembelajaran jarak jauh tidak bisa dilakukan maka pembelajaran atau magang kerja tatap muka harus memperhatikan protokol kesehatan yang telah ada.

Menindaklanjuti Peraturan Walikota tersebut, pada tanggal 10 Juli 2020 Dinas Pendidikan Kota Surabaya mengeluarkan Surat Kepala Dinas Pendidikan Kota Surabaya Nomor 800/1 1818/436.7.1/2020 tentang Pelaksanaan Pembelajaran Tahun Ajaran 2020/2021 pada Kondisi Pandemi Corona Virus Disease (COVID-19) dengan Tatanan Normal Baru. Melalui surat keputusan tersebut, Dinas Pendidikan kota Surabaya mewajibkan bagi seluruh satuan pendidikan di lingkungan Dinas Pendidikan Kota Surabaya untuk melakukan pembelajaran secara daring (dalam jaringan) dan dilarang melakukan proses pembelajaran tatap muka.

Pelaksanaan suatu kebijakan tentu saja tidak terlepas dari berbagai macam permasalahan yang ada, hal ini dapat dilihat berdasarkan kendala-kendala dalam pencapaian tujuannya. Salah satunya terletak pada Kecamatan Bulak. Bulak merupakan salah satu kecamatan yang ada di Kota Surabaya. Berdasarkan data dari (surabayakota.bps.go.id) di Kecamatan Bulak terdapat sekitar 21.530 jumlah penduduk. Sebagian besar penduduk berprofesi sebagai nelayan, pedagang ikan, dan juga 
melakukan kegiatan yang berkaitan dengan hasil tangkapan laut seperti usaha rumahan olahan hasil laut, diantaranya berupa usaha kerupuk terung, kerupuk teripang, keripik kentang udang dan lain-lainnya. Rata-rata penghasilan penduduk di Kecamatan Bulak masih tergolong rendah. Selain itu di Kecamatan Bulak juga memiliki tingkat pendidikan yang rendah dari kecamatan lain yang ada di Surabaya.

Rata-rata mata pencaharian orang tua di Kecamatan Bulak adalah sebagai nelayan atau pedagang ikan sehingga orangtua yang sibuk bekerja juga tidak dapat memantau perkembangan belajar anaknya secara maksimal (Hasibuan, 2019). Selain itu penghasilan penduduk juga masih tergolong rendah sehingga orangtua yang kurang mampu tidak dapat membelikan anaknya ponsel, laptop, atau komputer sendiri sehingga harus meminjam kepada saudara.

Berdasarkan fenomena diatas peneliti tertarik untuk melihat bagaimana Implementasi Kebijakan Belajar dari Rumah dengan Tatanan Normal Baru pada Sekolah Dasar di Kecamatan Bulak Kota Surabaya, sehingga penelitian ini bertujuan untuk mendeskripsikan Implementasi Kebijakan Belajar dari Rumah dengan Tatanan Normal Baru pada Sekolah Dasar di Kecamatan Bulak Kota Surabaya.

\section{METODOLOGI}

Jenis penelitian yang digunakan dalam penelitian ini yaitu deskriptif kualitatif . penelitian ini memfokuskan untuk menganalisis Implementasi Kebijakan Belajar dari Rumah dengan Tatanan Normal Baru pada Sekolah Dasar di Kecamatan Bulak Kota Surabaya dengan menggunakan teori model implementasi dari Edward III sebagaimana yang dikutip oleh Anggara (2014) bahwa terdapat empat fokus dalam melihat implementasi kebijakan yaitu komunikasi, sumber daya, disposisi, dan struktur birokrasi.

Penelitian ini menggunakan data primer yang berasal dari key informan dan data sekunder yang berasal dari dokumen penunjang. Teknik pengumpulan data yang digunakan dalam penelitian ini yaitu wawancara kepada para informan, observasi secara langsung di lapangan, serta dokumentasi. Kemudian model analisis data yang digunakan dalam penelitian ini yaitu menggunakan model analisis data interaktif dari Miles et al. (2014) yaitu pengumpulan data, penyajian data, kondensasi data, serta penarikan kesimpulan dan verifikasi.

\section{HASIL DAN PEMBAHASAN}

Dinas Pendidikan Kota Surabaya mengeluarkan Surat Kepala Dinas Pendidikan Kota Surabaya Nomor 800/1 1818/436.7.1/2020 tentang Pelaksanaan Pembelajaran Tahun Ajaran 2020/2021 pada Kondisi Pandemi Corona Virus Disease (COVID-19) dengan Tatanan Normal Baru. Melalui surat keputusan tersebut, Dinas Pendidikan kota Surabaya mewajibkan bagi seluruh satuan pendidikan di lingkungan Dinas Pendidikan Kota Surabaya untuk melakukan 


\section{Journal Publicuho}

ISSN2621-1351 (online), ISSN 2685-0729 (print)

Volume 4 Number 2 (May-July), (2021)pp. 711-718

Accredited SINTA SK.NOMOR 28/E/KPT/2019

Open Access at:http://ojs.uho.ac.id/index.php/PUBLICUHO/index

DOI: 10.35817/jpu.v4i2.19064

pembelajaran secara daring (dalam jaringan) dan dilarang melakukan proses pembelajaran tatap muka pada satuan Pendidikan termasuk Layanan Orientasi Siswa (LOS) atau Masa Pengenalan Lingkungan Sekolah (MPLS) dan tetap melanjutkan kegiatan Belajar dari Rumah (BDR).

Sebagaimana dengan adanya kebijakan belajar dari rumah dengan tatanan normal baru yang dilakukan dengan metode pembelajaran daring, tentu guru harus bekerja lebih keras lagi untuk menyampaikan materi yang diberikan secara online kepada muridnya, oleh karena itu perlu ada kerja sama antara guru dan orang tua dalam pelaksanaannya. Kecamatan Bulak merupakan kecamatan di wilayah Kota Surabaya dengan tingkat pendidikan orang tuanya tamatan SD terbanyak. Sehingga mengakibatkan orang tua tidak dapat mendampingi dan mengajarkan anaknya karena gagap teknologi dan anak harus belajar secara mandiri.

Guna mengetahui terimplementasikannya kebijakan belajar dari rumah dengan tatanan normal baru pada Sekolah Dasar di Kecamatan Bulak Kota Surabaya maka dilakukan analisis implementasi dengan teori model implementasi Edward III dengan 4 faktor yang akan dijabarkan lebih lanjut dibawah ini:

\section{Komunikasi}

Komunikasi merupakan salah satu fokus yang memiliki peran yang cukup penting dalam keberhasilan implementasi suatu kebijakan. Dalam mengimplementasikan kebijakan pembelajaran dari rumah diperlukan komunikasi yang baik sehingga mendapatkan dukungan serta komitmen dari pelaksana kebijakan dan sasaran kebijakan. Menurut Agustino sebagaimana dikutip oleh Anggara (2014:251) bahwa pentransmisian (penyaluran) komunikasi diperlukan agar para pembuat keputusan dan para implementor semakin memahami kebijakan yang nantinya akan diterapkan di masyarakat. Pendapat tersebut telah sesuai dengan proses implementasi kebijakan pembelajaran dari rumah terdapat penyaluran informasi mengenai pembelajaran dari rumah dilakukan oleh Dinas Pendidikan Kota Surabaya kepada para Kepala Sekolah Sekolah Dasar di Kecamatan Bulak Kota Surabaya melalui virtual zoom meeting. Kemudian berkaitan pentransmisian informasi dari sekolah kepada murid dan wali murid dilakukan melalui pesan tertulis dan sosialisasi saat awal pandemi sebelum pembelajaran dari rumah dilakukan. Segala informasi mengenai kebijakan pembelajaran dari rumah disalurkan oleh Dinas Pendidikan Kota Surabaya melalui live youtube Dispendik.

Kemudian komunikasi pada proses implementasi kebijakan pembelajaran dari rumah telah disampaikan kepada pihak sekolah dan wali murid melalui pelatihan guru dan sosialisasi kepada walimurid. Sehingga pihak sekolah dan wali murid memahami dengan jelas dan baik terkait kebijakan tersebut. Penyampaian informasi dalam komunikasi akan terlaksana 
dengan baik apabila proses dan cara penyampaian informasinya dilakukan dengan tepat. Kejelasan maksud dan tujuan adalah hal yang mutlak sehingga dapat diimplementasikan sesuai dengan yang direncanakan dan diputuskan sebelumnya.

Selain pentransmisian dan kejelasan komunikasi, konsistensi juga dibutuhkan dalam proses komunikasi untuk melaksanakan suatu kebijakan. Dalam pelaksanaan kebijakan pembelajaran dari rumah, koordinasi antara Dinas Pendidikan Kota Surabaya dalam hal ini melalui Bidang Guru dan Tenaga Kependidikan (GTK) dengan pihak sekolah dalam hal ini melalui pengawas sekolah yang dilakukan secara rutin satu minggu satu kali melalui virtual zoom meeting. Pengawas sekolah melaporkan perkembangan pelaksanaan belajar dari rumah kepada Dinas Pendidikan Kota Surabaya. Sehingga dapat disimpulkan bahwa komunikasi pada sub fokus konsistensi telah dilakukan dengan konsisten dan terimplementasi dengan baik.

\section{Sumber Daya}

Sumberdaya merupakan salah satu fokus penting dalam mendukung implementasi kebijakan publik, hal ini berkaitan erat dengan kemampuan pelaksana dalam melaksanakan kebijakan tersebut sesuai arahan yang ada. Pada proses implementasi pembelajaran dari rumah, guru atau tenaga pendidik di Sekolah Dasar wilayah Kecamatan Bulak jumlahnya belum memadai mengingat jumlah murid dan sekolah dasar di Kecamatan Bulak cukup banyak. Kemudian berkaitan dengan kemampuan dan skill guru yang ada masih terdapat guru yang belum paham mengenai teknologi yang digunakan dalam belajar dari rumah. Sehingga dapat disimpulkan bahwa sumber daya subfokus staff belum tercukupi jumlah dan kemampuannya melakukan pembelajaran dari rumah. Pembelajaran dari rumah telah memiliki informasi mengenai pedoman pelaksanaan serta memiliki petunjuk teknis.

Selain ketersediaan staff dan informasi dibutuhkan dalam implementasi kebijakan, kewenangan juga merupakan hal yang penting dan harus dimiliki dalam proses implementasi suatu kebijakan. Pihak sekolah dan guru memiliki kewenangan dalam menentukan media pembelajaran dari rumah yang dapat mempermudah akses serta pengoperasian murid dan wali murid dalam proses belajar mengajar. Sehingga dapat disimpulkan bahwa sumber daya subfokus kewenangan telah dimiliki oleh pihak sekolah dan guru dalam melaksanakan pembelajaran dari rumah.

Dalam proses pembelajaran dari rumah juga telah terdapat fasilitas yang disediakan guna dalam menunjang pelaksanaan kebijakan tersebut. Maka dapat dikatakan bahwa ketersediaan fasilitas telah disediakan dengan baik. Fasilitas fisik sebagai sarana dan prasarana pendukung yang diperlukan dalam memperlancar proses implementasi kebijakan. Jika fasilitas fisik tidak disediakan dengan memadai, maka proses implementasi kebijakan juga tidak akan berhasil dengan sepenuhnya. 


\section{Journal Publicuho}

ISSN2621-1351 (online), ISSN 2685-0729 (print)

Volume 4 Number 2 (May-July), (2021)pp. 711-718

Accredited SINTA SK.NOMOR 28/E/KPT/2019

Open Access at:http://ojs.uho.ac.id/index.php/PUBLICUHO/index

DOI: 10.35817/jpu.v4i2.19064

\section{Disposisi}

Dalam proses implementasi kebijakan pembelajaran dari rumah guru dan pihak sekolah telah memahami ketentuan-ketentuan dalam menerapkan kebijakan tersebut. Kemudian pada proses implementasi kebijakan pembelajaran dari rumah, kebijakan dari Walikota Surabaya terkait pembelajaran dari rumah telah dilaksanakan dengan baik oleh pihak sekolah dan guru tanpa adanya resistensi atau penolakan dari guru atas kebijakan tersebut karena demi keselamatan dan kesehatan bersama untuk meminimalisir dampak penyebaran COVID-19. Penolakan terjadi pada walimurid yang menginginkan proses pembelajaran dilakukan secara langsung karena beranggapan murid akan lebih menyerap ilmu yang disampaikan dengan baik. Selain itu implementasi kebijakan pembelajaran dari rumah, pihak sekolah dan guru telah merespon dan melaksanakan pembelajaran dari rumah secara intens dan terus menerus sesuai jadwal yang sudah ditentukan sebelumnya. Hanya waktu atau durasi setiap mata pelajaran lebih singkat daripada pembelajaran secara langsung.

\section{Struktur Birokrasi}

Struktur birokrasi merupakan hal penting yang harus dimiliki oleh setiap institusi terlebih dalam melaksanakan sebuah kebijakan. Dalam proses implementasi pembelajaran dari rumah terkait Standar Operasional Prosedur telah disediakan dalam proses pelaksanaan pembelajaran dari rumah. Kemudian juga terdapat struktur pelaksana Satgas Pendidikan di tingkat sekolah. Terdapat ketentuan-tertentuan untuk menyiapkan segala fasilitas yang dibutuhkan. Sehingga dapat disimpulkan bahwa fokus struktur birokrasi telah diimplementasikan dengan baik.

\section{KESIMPULAN}

kesimpulan hasil penelitian adalah sebagai berikut:

1. Fokus komunikasi dapat dinyatakan bahwa telah terimplementasi dengan baik. Proses penyaluran atau transmisi komunikasi dalam pembelajaran dari rumah telah memuat maksud dan tujuan dari kebijakan tersebut. Kemudian penyampaian informasi dalam komunikasi antara pihak sekolah dalam komunikasi kepada walimurid telah disampaikan dengan baik dan jelas. Kemudian dalam konsistensi, koordinasi antara Dinas Pendidikan Kota Surabaya dengan pihak sekolah melalui pengawas sekolah telah dilaksanakan dengan konsisten

2. Fokus sumber daya dapat dikatakan belum terimplementasi dengan baik. Pada sub fokus ketersediaan staf dalam hal ini adalah guru belum jumlahnya serta kemampuannya dalam melakukan pembeajaran dari rumah. Kemudian pada sub fokus informasi telah memiliki pedoman peraturan yang berasal dari Peraturan Walikota Selanjutnya pada sub fokus kewenangan juga telah dimiliki oleh pihak 
sekolah dan guru dalam menentukan media pembelajaran dari rumah. Kemudian pada sub fokus fasilitas telah terlaksana dengan baik

3. Fokus disposisi dapat dinyatakan bahwa telah terimplementasi. Hal ini dapat dilihat pada kognisi bahwa guru telah memahami dengan baik mengenai ketentuanketentuan dalam menerapkan pembelajaran dari rumah. Kemudian pada arahan dan tanggapan pelaksana telah dilakukan oleh pihak sekolah dan guru tanpa adanya resistensi atau penolakan terkait kebijakan pembelajaran dari rumah. Selanjutnya pada intensitas respon atau tanggapan pelaksanaan juga telah direspon oleh guru dalam melaksanakan pembelajaran darirumah dengan intens serta terus-menerus

4. Fokus struktur birokrasi telah terimplementasi dengan baik. Terkait Standar Operasional Prosedur telah disediakan dalam proses pelaksanaan pembelajaran dari rumah. Kemudian juga terdapat struktur pelaksana Satgas Pendidikan di tingkat sekolah.

5. Dengan demikian Implementasi Kebijakan Belajar dari Rumah dengan Tatanan Normal Baru pada Sekolah Dasar di Kecamatan Bulak Kota Surabaya belum terimplementasi dengan baik secara keseluruhan.

\section{REFERENSI}

Anggara, S. (2014). Kebijakan Publik. Bandung: CV Pustaka Setia.

Arifa, F. (2020). Tantangan Pelaksanaan Kebijakan Belajar Dari Rumah Dalam Masa Darurat COVID-19. Info Singkat: Kajian Singkat Terhadap Isu Aktual dan Strategis, 12(7). 14-18.

Hasibuan, MS., Simamarta \& Sudirman. (2019). E-Learning: Implementasi, Strategi, dan Inovasinya. Medan: Yayasan Kita Menulis.

Maulah \& Ummah. 92020). Persepsi Mahasiswa Biologi terhadap Perkuliahan Daring Sebagai Sarana Pembelajaran Selama Pandemi COVID-19. ALVEOLI:Jurnal Pendidikan Biologi, $1(12), 49-61$.

Peraturan Walikota Surabaya Nomor 28 Tahun 2020 Tentang Pedoman Tatanan Normal Bari pada Kondisi Pandemi COVID-19 di Kota Surabaya

Prasetyaningyas. (2020). Pelaksanaan Belajar Dari Rumah Secara Online Selama Darurat COVID-19 di SMPN 1 Semin. Ideguru: Jurnal Karya Ilmiah Guru. 5(1). 86-94.

Siyoto \& Sodik. (2015). Dasar Metodologi Penelitian. Yogyakarta: Literasi Media Publishing.

Surat Edaran Nomor 15 Tahun 2020 Tentang Pedoman Penyelenggaraan Belajar Dari Rumah Dalam Masa Darurat Penyebara COVID-19.

Surat Edaran Mendikbud Nomor 4 Taun 2020 Tentang Pelaksanaan Kebijakan Pendidikan Dalam Masa Darurat Penyebaran COVID-19.

Surat Kepala Dinas Pendidikan Kota Surabaya Nomor 800/11818/436.7.1/2020 Tentang Pelaksanaan Pembelajaran Tahun Ajaran 2020/2021 Pada Kondisi Pandemi COVID-19 dengan Tatanan Normal Baru.

Undang-Undang Nomor 20 Tahun 2003 Tentang Sistem Pendidikan Nasional. 